\title{
Helseproblem og rusmiddelbruk hos nordtrøndersk ungdom
}

\author{
Ungdom med tidlege åtferds- og helseproblem utviklar oftare sjølv- \\ mordstankar og alkohol- og stoffbruk.
}

Klinisk har ein lenge sett samband mellom rus og dårleg helse hos ungdom og auke i sjølvmordstankar etter puberteten, men det har mangla forsking. I studien ville vi finne prevalensen av alkoholbruk og sambandet mellom bruk av alkohol og åtferds- og helseproblem. I tillegg undersøkte vi risikofaktorar for utvikling av hyppig alkoholbruk, bruk av illegale rusmiddel og sjølvmordstankar gjennom tenåra.

I Ung-HUNT 1 (1995-97) vart all ungdom (13-19 år) i Nord-Trøndelag undersøkt, totalt $8983(91 \%$ av populasjonen i aldersgruppa), med spørjeskjema og målingar.

I Ung-HUNT 2 (2000-01) vart elevane i 2. og 3. klasse i vidaregåande skule undersøkte. 2399 ungdomar (81\%) var med i begge studiane. Epidemiologiske tverrsnittsmetodar og prospektive metodar vart nytta.

I 1995-97 hadde $80 \%$ av ungdomane prøvd alkohol, $57 \%$ hadde vore fulle og $29 \%$ hadde vore fulle meir enn ti gonger. Det var sterkt samband mellom hyppige alkoholforgiftingar og dårleg helse, særleg gjeldt det vanskar med merksemd, åtferd og kroppssmerte. Tidlege åtferdsproblem og alkoholforgiftingar dobla risikoen for høg alkoholbruk og bruk av illegale rusmiddel seinare i tenåra. Både tidlege vanskar med merksemd, åtferd og kroppssmerte samt angst og depressive symptom var sterkt knytt til utvikling av sjølvmordstankar. Overvekt auka også risikoen for seinare sjølvmordstankar.

Vi konkluderer med at alkoholbruk, særleg episodisk fyll, er vanleg hos tenåringar i Nord-Trøndelag og at dette er assosiert med helseproblem. Ungdom med tidlege åtferdsproblem og ungdom som byrjar å drikke alkohol tidleg, får oftare hyppig alkoholbruk og debut med illegale rusmiddel seinare i ungdomsåra.

\section{Arve Strandheim}

arve.strandheim@ntnu.no

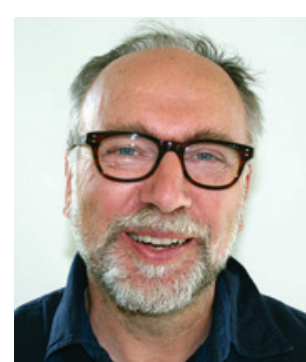

Arve Strandheim. Foto: Maria C. Stuifbergen

\section{Disputas}

Arve Strandheim disputerte for ph.d.-graden ved Norges teknisk-naturvitenskapelige universitet 10.5. 2013. Tittelen på avhandlingen er Substance use and health problems in adolescents. The Young-HUNT study, North-Trøndelag, Norway.

\section{Stamceller i behandlingen av bruskskader}

Stamceller kan bli viktige i behandlingen av bruskskader, men dagens
metoder for å styre utviklingen av en bruskcelle i laboratoriet må forbedres.

Brusken er skadet hos ca. $20 \%$ av pasienter med korsbåndsskader. Ved større bruskskader i kneet kan pasientene ha like dårlig funksjon som pasienter som venter på kneprotese. Bruskskader kan i dag behandles med transplantasjon av pasientens egne bruskceller dyrket i laboratoriet, men resultatet av denne behandlingen er ikke alltid tilfredsstillende.

Vi undersøkte om mesenkymale stamceller fra fettvev eller beinmarg kan brukes i stedet for pasientens egne bruskceller. Vi fant at stamceller fra beinmarg lettere lot seg differensiere til bruskliknende celler, men at ingen av stamcelletypene laget fullverdige bruskceller i laboratoriet. I en dyrestudie med beinmargsstamceller fra kanin fant vi at det var bedre kvalitet på reparasjonsvevet i bruskskader behandlet med stamceller. Det var likevel ikke bedre fylling av defekten enn der det ikke var transplantert inn celler.

For bedre å forstå prosessen når en stamcelle differensieres mot brusk, sammenliknet vi mikro-RNA-profilen i stamceller under differensiering med uttrykket i native bruskceller. Her oppdaget vi at $m i R-140$, som er et mikro-RNA spesifikt for brusk, regulerte genet $R A L A$, som ikke tidligere er blitt vist å ha betydning for bruskdifferensiering.

Resultatene underbygger potensialet stamceller kan få i fremtidige behandlinger for bruskskader og har bidratt med kunnskap om viktige forskjeller mellom native bruskceller og bruskceller fremstilt fra stamceller i laboratoriet.

Rune Bruhn Jakobsen r.b.jakobsen@gmail.com

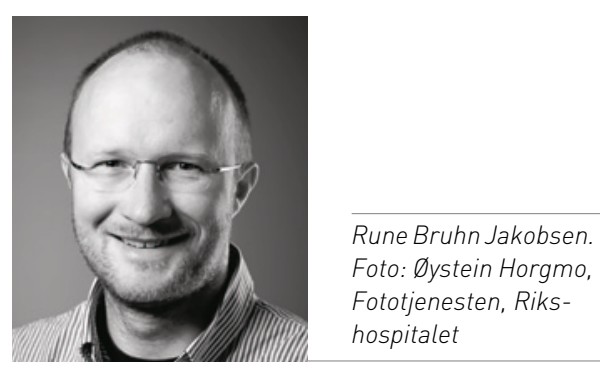

Disputas

Rune Bruhn Jakobsen disputerte for ph.d.graden ved Universitetet i Oslo 16.6. 2014. Tittelen på avhandlingen er Mesenchymal stem cells in cartilage repair - studies of chondrogenesis in vitro and in vivo. 